\title{
Follicular fluid electrolytes and osmolality in cyclic pigs
}

\author{
J. F. Knudsen, L. J. Litkowski*, T. L. Wilson*, H. D. Guthrie $\dagger$ \\ and S. K. Batta
}

Department of Physiology and *Division of Nephrology, University of Maryland School of Medicine, Baltimore, Maryland 21201, and $†$ United States Department of Agriculture, Beltsville, Maryland 20705, U.S.A.

\begin{abstract}
Summary. Sodium and osmolal concentrations of porcine follicular fluid in the cyclic pig did not vary significantly during the oestrous cycle, and were similar to those in plasma. The $\mathrm{K}^{+}$concentration was greater in small (Days 12-13) and medium-sized (Day 16) follicles than in plasma or large (Day 18-oestrus) follicles of cyclic sows. In contrast, follicular fluid obtained from slaughterhouse material had higher potassium and osmolality, and lower sodium values, which are assumed to be due to post-mortem changes.
\end{abstract}

\section{Introduction}

A thorough understanding of the events which influence oocyte maturation requires examination of the chemical and physical properties of the follicular fluid microenvironment during the oestrous cycle. To date, most studies of oocyte physiology in the pig have utilized ovaries obtained from slaughterhouses. However, the possibility of post-mortem changes in these ovaries and the follicular fluid has been considered only occasionally, and may account for conflicting data on electrolytes and acid-base chemistries in porcine follicular fluid (Schuetz \& Anisowicz, 1974; Chang, Jones, Ellefson \& Ryan, 1976; Knudsen, Litkowski, Wilson, Guthrie, \& Batta, 1978). For example, Knudsen et al. (1978) attributed variations in acid-base values in porcine follicular fluid from slaughterhouse material and that from known cyclic laboratory animals to differences between methods of sample collection and storage. Eiler \& Nalbandov (1977) also found significant differences in follicular fluid steroid concentrations of such samples. Edwards (1974) suggested that follicular fluid for in-vitro studies should be collected from fresh samples to avoid degenerative changes.

The present report examines $\mathrm{Na}^{+}, \mathrm{K}^{+}$and osmolality of follicular fluid on different days of the oestrous cycle in the pig, and compares these values with similar determinations made from follicular fluid obtained from slaughterhouse material.

\section{Materials and Methods}

The cyclic sows used were sexually mature Yorkshire and Duroc sows $(200-250 \mathrm{~kg})$ with a history of at least one regular oestrous cycle. To obtain the maximum number of small (1-2 $\mathrm{mm}$ ), medium (3-5 mm), and large $(6-11 \mathrm{~mm})$ follicles, sows were laparotomized on Days 12 13,16 and 18 -oestrus. Following anaesthesia (sodium pentobarbitone, $10 \mathrm{mg} / \mathrm{kg}$ ), blood from the jugular vein was collected in heparinized tubes and immediately stored on ice until analysis. Fluid was collected with a $1-\mathrm{ml}$ tuberculin syringe fitted with a 23 -gauge needle from individual 
follicles within 1-2 min of ovarian extirpation, and stored on ice. Fluid from follicles of similar size was pooled to provide an adequate volume (see below) for analysis. Plasma and follicular fluid were assayed on the day of the experiment, with the average time interval between collection and analysis being $2.5 \mathrm{~h}$. For comparison, porcine ovaries were obtained from a slaughterhouse and placed in $0.9 \%(\mathrm{w} / \mathrm{v}) \mathrm{NaCl}$ (unbuffered; $\mathrm{pH} 6.0)$ at room temperature. The time between slaughter and follicular fluid recovery was $3-4 \mathrm{~h}$, with analysis on the same day. No distinction was made between atretic and non-atretic follicles for either group of samples.

Samples of blood and follicular fluid were centrifuged for $10 \mathrm{~min}$ at $7000 \mathrm{~g}_{\max }$ to remove, respectively, blood cells and oocytes/granulosa cells. Aliquots $(50 \mu \mathrm{l})$ of the supernates were then assayed for $\mathrm{Na}^{+}$and $\mathrm{K}^{+}$using a flame emission photometer (IL243: Instrumentation Laboratories, Inc., Watertown, Massachusetts) with a precision of $\pm 1.0 \mathrm{mmol} / 1$ for $\mathrm{Na}^{+}$, and $\pm 0.05 \mathrm{mmol} / 1$ for $\mathrm{K}^{+}$. Additional aliquots $(250 \mu \mathrm{l})$ of the supernates were used for the determination of osmolality by freezing point depression on a 3D II osmometer (Advanced Instruments, Inc., Needham Heights, Massachusetts) with a precision of $\pm 2 \mathrm{mosmol} / \mathrm{kg}$. Results (means \pm s.e.m.) were tested for significance by Duncan's Multiple Range Test, and Student's $t$ test where applicable (Steel \& Torrie, 1960).

\section{Results}

The data presented in Tables 1 and 2 indicate that electrolyte and osmolal values in porcine follicular fluid varied with the method of sample collection. For example, potassium concentrations in follicular fluid of ovaries obtained from the slaughterhouse were 2- to 3-fold greater than in plasma or in fluid from follicles of similar sizes in cyclic pigs.

Sodium concentrations did not differ so greatly, but were lower in the slaughterhouse material.

The osmolality of ovarian fluid from cyclic pigs did not vary significantly with the stage of the oestrous cycle, and was similar to plasma values (Table 2). In contrast, the osmolality of ovarian follicular fluid in slaughterhouse materials was on average $9 \mathrm{mosmol} / \mathrm{kg}$ higher than that in plasma or follicular fluid of the cyclic pig, and varied inversely with the size of the follicle.

Table 1. $\mathrm{Na}^{+}$and $\mathrm{K}^{+}$concentrations in porcine venous blood and follicular fluid at different stages of the oestrous cycle

\begin{tabular}{|c|c|c|c|c|c|}
\hline Group & $\begin{array}{l}\text { Day of } \\
\text { cycle }\end{array}$ & $\begin{array}{l}\text { No. of } \\
\text { sows }\end{array}$ & $\begin{array}{c}\text { Follicle size } \\
\text { (no.) }\end{array}$ & $\underset{(\mathrm{mmol} / \mathrm{l})}{\mathrm{Na}^{+}}$ & $\underset{(\mathrm{mmol} / \mathrm{l})}{\mathrm{K}^{+}}$ \\
\hline I Plasma & - & 5 & - & $140 \cdot 0 \pm 1.9$ & $4.84 \pm 0.21$ \\
\hline \multirow[t]{3}{*}{$\begin{array}{l}\text { II Follicular fluid } \\
\text { from cyclic pigs }\end{array}$} & $12-13$ & 4 & $\begin{array}{l}\text { Small } \\
(155)\end{array}$ & $145 \cdot 2 \pm 0.6^{*}$ & $5 \cdot 55 \underset{(6)}{ \pm} 0.27 \ddagger$ \\
\hline & 16 & 4 & $\begin{array}{l}\text { Medium } \\
(81)\end{array}$ & $143 \cdot 0 \pm \frac{ \pm}{(6)} 1 \cdot 3$ & $5.52 \pm \underset{(4)}{ \pm 0.23 \ddagger}$ \\
\hline & 18-oestrus & 4 & $\begin{array}{l}\text { Large } \\
\text { (19) }\end{array}$ & $144 \cdot 8 \pm 0.3^{*}$ & $4.92 \pm 0.21$ \\
\hline \multirow{3}{*}{$\begin{array}{l}\text { III Follicular fluid } \\
\text { from slaughterhouse } \\
\text { material }\end{array}$} & - & 3 & $\begin{array}{l}\text { Small } \\
(200)\end{array}$ & $135 \cdot 5 \pm 1 \cdot 3$ & $12 \cdot 16 \pm \frac{(7)}{0.22 \dagger}$ \\
\hline & - & 4 & $\begin{array}{l}\text { Medium } \\
\quad(96)\end{array}$ & $\begin{array}{c}140 \cdot 7 \pm 1 \cdot 6 \\
(10)\end{array}$ & $\begin{array}{c}10.27 \pm 0.53 \dagger \\
(10)\end{array}$ \\
\hline & - & 4 & $\begin{array}{l}\text { Large } \\
\text { (29) }\end{array}$ & $\begin{array}{c}138.9 \pm 0.9 \\
(8)\end{array}$ & $8.89 \pm 0.28 \dagger$ \\
\hline
\end{tabular}

Values are mean \pm s.e.m. for the no. of determinations given in parentheses.

* Value significantly greater than that for follicles of corresponding size in Group III $(P<0.05)$.

+ Value significantly greater than those for plasma and follicles of corresponding size in Group II $(P<0.01)$.

$\ddagger$ Value significantly greater than that for plasma $(P<0.05)$. 
Table 2. Mean \pm s.e.m. (no. of observations in parentheses) osmolal concentrations in porcine venous blood and follicular fluid

\begin{tabular}{|c|c|c|c|c|}
\hline Group & $\begin{array}{l}\text { Day of } \\
\text { cycle }\end{array}$ & $\begin{array}{l}\text { No. of } \\
\text { sows }\end{array}$ & $\begin{array}{l}\text { Follicle size } \\
\text { (no.) }\end{array}$ & $\begin{array}{l}\text { Osmolality } \\
\text { (mosmol/kg) }\end{array}$ \\
\hline I Plasma & - & 5 & - & $300 \cdot 7 \pm 1 \cdot 6$ \\
\hline \multirow[t]{3}{*}{$\begin{array}{l}\text { II Follicular fluid } \\
\text { from cyclic pigs }\end{array}$} & $12-13$ & 3 & $\begin{array}{l}\text { Small } \\
(150)\end{array}$ & $302 \cdot 6 \pm 2 \cdot 0$ \\
\hline & 16 & 3 & $\begin{array}{l}\text { Medium } \\
(43)\end{array}$ & $\underset{(5)}{297 \cdot 3 \pm 1 \cdot 5}$ \\
\hline & $\begin{array}{c}18- \\
\text { oestrus }\end{array}$ & 6 & $\begin{array}{c}\text { Large } \\
(36)\end{array}$ & $\frac{305 \cdot 1 \pm 3 \cdot 0}{(8)}$ \\
\hline \multirow{3}{*}{$\begin{array}{l}\text { III Follicular fluid } \\
\text { from slaughterhouse } \\
\text { material }\end{array}$} & - & 16 & $\begin{array}{l}\text { Small } \\
(332)\end{array}$ & $\begin{array}{c}313.0 \pm 0.8^{*} \dagger \\
(8)\end{array}$ \\
\hline & - & 10 & $\underset{(197)}{\text { Medium }}$ & $\begin{array}{c}308 \cdot 1 \pm 0.9^{*} \dagger \\
(20)\end{array}$ \\
\hline & - & 6 & $\begin{array}{l}\text { Large } \\
(26)\end{array}$ & $\begin{array}{c}308 \cdot 4 \pm 2 \cdot 0 \dagger \\
(10)\end{array}$ \\
\hline
\end{tabular}

* Values significantly different from those in plasma and follicles of corresponding size in Group II $(P<0.05)$.

$\dagger$ Value significantly different from that in plasma $(P<0 \cdot 05)$.

\section{Discussion}

The data reported here comprise the first examination of $\mathrm{Na}^{+}, \mathrm{K}^{+}$, and osmolal concentrations of follicular fluid obtained from cyclic pigs on known days of the oestrous cycle. The values of $\mathrm{Na}^{+}$ and $\mathrm{K}^{+}$of porcine plasma corroborate the earlier findings of Cummings \& Kaiser (1959), and are within the normal range for human plasma. Values of osmolality for porcine plasma are slightly higher than those of other species, such as man (Edwards, 1974) and cow (Olds \& VanDemark, 1957).

In the cyclic pig, the $\mathrm{K}^{+}$concentration of porcine follicular fluid varied slightly during the days of the oestrous cycle examined. Though significant compared to plasma, it is not clear if the slightly higher $\mathrm{K}^{+}$values from small and medium-sized follicles reflect a physiological process of follicular maturation. Another possible explanation for this difference is extraneous contamination, since a larger number of small and medium-sized follicles had to be aspirated to provide sufficient volume for the analyses. Previous investigators (Schuetz \& Anisowicz, 1974; Chang et al., 1976) have reported even higher $\mathrm{K}^{+}$values in porcine follicular fluid from ovaries obtained from a slaughterhouse. The higher $\mathrm{K}^{+}$values of follicular fluid found in the slaughterhouse preparation suggest that the method of collection and storage of follicular fluid is critical. The anoxia and intrafollicular acidosis (Knudsen et al., 1978) which result from ischaemia before collection of follicular fluid could lead to post-mortem degeneration of granulosa cells with resultant loss of intracellular $\mathrm{K}^{+}$into the follicular fluid. Concomitant with this shift in $\mathrm{K}^{+}, \mathrm{Na}^{+}$moves in the opposite direction. The inverse relation between follicle size and follicular fluid $\mathrm{K}^{+}$in the slaughterhouse material is also consistent with this reasoning, since smaller follicles would accumulate relatively more $\mathrm{K}^{+}$, due partly to the greater surface area:volume ratio.

The $\mathrm{Na}^{+}$concentration of porcine follicular fluid was relatively constant throughout the oestrous cycle. Schuetz \& Anisowicz (1974) also reported that $\mathrm{Na}^{+}$was invariant with respect to follicular size, although the mean value for $\mathrm{Na}^{+}$reported by these investigators was lower than any of the values found in the present study. In the slaughterhouse material the $\mathrm{Na}^{+}$values for follicular fluid were lower than those obtained from fresh follicles. Chang et al. (1976) noted a similar pattern between "ice-stored" and "fresh" preparations, the latter more closely approximating serum $\mathrm{Na}^{+}$. Lower $\mathrm{Na}^{+}$values in follicular fluid of the slaughterhouse preparation may 
again reflect partial equilibration of $\mathrm{Na}^{+}$and $\mathrm{K}^{+}$between granulosa cells and follicular fluid, as suggested above. In addition, it is possible that $\mathrm{Na}^{+}$and $\mathrm{K}^{+}$within the follicle may equilibrate with the medium in which the ovaries are kept when transported to the laboratory. At the end of ovarian storage, this medium $(0.9 \% \mathrm{NaCl})$ was found to have a $\mathrm{K}^{+}$value of $10.05 \pm 0.45$ $\mathrm{mmol} / \mathrm{l}$, which we attribute mainly to haemolysis of red blood cells resulting from ovarian excision.

The present observations are particularly significant in light of the investigations of Powers \& Biggers (1976), who demonstrated that removal of external $\mathrm{Na}^{+}$from a chemically defined medium, or increasing the $\mathrm{K}^{+}$permeability of the oocyte, affected the maturation (germinal vesicle breakdown) of the isolated mouse oocyte. The hyperosmolality of porcine follicular fluid from ovaries obtained from a slaughterhouse is also of interest in view of the finding of McGaughey (1977) that osmolalities of this magnitude can cause poor oocyte maturation in in-vitro cultures.

Our findings suggest that studies which utilize follicular fluid require critical attention to the limitations inherent in the use of slaughterhouse preparations.

We thank T. Smith, C. Hutchins and M. Gillin for secretarial assistance.

\section{References}

Chang, S.C.S., Jones, J.D., Ellefson, R.D. \& Ryan, R.J. (1976) The porcine ovarian follicle: I. Selected chemical analysis of follicular fluid at different developmental stages. Biol. Reprod. 15, 321-328.

Cummings, J.N. \& Kaiser, I.H. (1959) The blood gases, $\mathrm{pH}$ and plasma electrolytes of the sow and fetal pig at 106 days of pregnancy. Am. J. Obstet. Gynec. 77, 10-17.

Edwards, R.G. (1974) Follicular fluid. J. Reprod. Fert. 37, 189-219.

Eiler, H. \& Nalbandov, A.V. (1977) Sex steroids in follicular fluid during the estrous cycle in pigs. Endocrinology 100, 331-338.

Knudsen, J.F., Litkowski, L.J., Wilson, T.L., Guthrie, H.D. \& Batta, S.K. (1978) Concentrations of hydrogen ions, oxygen, carbon dioxide and bicarbonate in porcine follicular fluid. J. Endocr. 79, 249-250.
MeGaughey, R.W. (1977) The maturation of porcine oocytes in minimal defined culture media with varied macromolecular supplements and varied osmolality. Expl Cell Res. 109, 25-30.

Olds, D. \& VanDemark, N.L. (1957) Composition of luminal fluids in bovine female genitalia. Fert. Steril. 8, 345-354.

Powers, R.D. \& Biggers, J.O. (1976) Inhibition of mouse oocyte maturation by cell membrane potential hyperpolarization. J. Cell Biol. 70, 352a.

Schuetz, A. W. \& Anisowicz, A. (1974) Cation and protein composition of ovarian follicular fluid of the pig: relation to follicle size. Biol. Reprod. 11, 64-72.

Steel, R.G.D. \& Torrie, J.H. (1960) Principles and Procedures of Statistics. McGraw-Hill, New York.

Received 20 February 1979 